\title{
STATISTICAL ANALYSIS OF EPISTAXIS
}

\author{
SHIRO MURATA, M.D., AKIO MAESAKA, M.D., TAMEO MIYAZAKI, M.D., \\ KOZI KINOSITA, M.D., KAZUHISA KITAGAWA, M.D., YUMIKO TAZIKA, M.D., \\ TORU TAKIMOTO, M.D. AND MITSURU KASE, M.D. \\ Department of Otolaryngology, Kanazawa University School of Medicine. Kanazawa.
}

(Director: R. Umeda, M.D.)

\begin{abstract}
Nine hundred and fifty one cases of epistaxis were observed for the past 7 years. Epistaxis was observed more frequently in males than in females and was frequently observed in children.

It occured more frequently from May to August, showing a peak in June.

The negative correlation was observed statistically between the frequency of epistaxis and the atmospheric pressure.

Hemorrhagic diathesis was examined in 114 cases. About 28 per cent of them showed abnormality, especially in the capillaly fragility.

Children with nasal bleeding showed the tendency of disliking of foods containing vitamine $\mathrm{C}$.
\end{abstract}

A81-0655-32989

鼻 出血 の 統 計 的 観 察

金沢大学医学部耳鼻咽喉科学教室 (主任：梅田良三教授)

村田志朗, 前坂明男, 宮崎為夫, 木下弘治, 北川和久, 田近由美子, 滝元 徹, 加勢 満

\section{緒言}

耳鼻咽喉科領域に打いては，血液疾患に代表される全 身的出血傾向の一分症としての鼻出血は存外末れであ り，原因不明の鼻出血が大部分を占めている．その出血 機序に関しては，多くの深い研究がなされているとはい え、いまだ不明な点もあり，治療においても多くは対症 療法にすまされているのが現状である，本疾患は短時日 に治療することが多いが, 症例によっては大量の輸血や 輸液を余儀なくされわれわれ耳鼻科医にとってずいぶん 手をわずらわされることもある，また反復性の鼻出血を 例にとるならば，患者にとっても，家族にとっても鼻出 血がいつ再発するか不安であり，精神的な苦痛は大であ ると想像される。鼻出血に関して各研究機関からの報告 があるが，今回，鼻出血を主訴として受診した患者の過 去 7 年間の，特に自発性鼻出血を中心とした臨床的，統 計的観察を行ったので，その結果を報告する．

\section{第 I 章 臨床的䅐察}

昭和 42 年から 48 年の 7 年間に自発性鼻出血と診断した 951 名について, 外来患者総数に対寸る比率, 性別頻度,
年秢分布, 年齢別男女分布, 月別患者分布を調查した。

1）鼻出血患者の外来患者総数に対する比率

7 年問を平均すると約 $3.7 \%$ である（表 1). この比率 は大阪大学 ${ }^{1}$ の $1.8 \%$, 東京医科大学 ${ }^{2}$ の $2.1 \%$ に比して かなり高率である。

2) 性別頻度

各年とも男子が多数であり， 7 年間を通し平均する と, 男子 $59.9 \%$ ，女子 $40.1 \%$ である(表 2$)$. 渡部”らが 指摘するごとく, 外来患者数は男子が多い傾向にあるた め，この比率を即鼻出血男女比とみることはできない

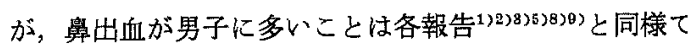
ある. 当疾患にて男子優位であることに関して，渡辺 ${ }^{9}$ らは各種止血剂にて効果の認められなかった10例の青年 男子鼻出血患者に対し，女性ホルモンを使用し，9例に 有効であったとして，一種のホルモン過剩による男女性 ホルモンこの不均衡が鼻出血発来の原因ではないかと燐 推している. 臨床的には，卵单ホルモン投与による出血 傾向の改善は指摘されていることであるが20)，鼻出血と ホルモンとの詳細な関倸は不明である。成書仙とれた。 
表 1 鼻出血患者の外来患者総数に対する比率

\begin{tabular}{c|r|r|r}
\hline 昭和 & 鼻出血患者数 & 外来患者総数 & \multicolumn{1}{|c}{$\%$} \\
\hline 42 & 146 & 4,073 & 3.5 \\
43 & 142 & 3,728 & 3.8 \\
44 & 118 & 3,806 & 3.1 \\
45 & 122 & 3,588 & 3.8 \\
46 & 137 & 3,605 & 4.6 \\
47 & 162 & 3,557 & 3.4 \\
48 & 124 & 3,615 & 3.7 \\
\hline
\end{tabular}

表 2 鼻出血患者の性別分類

\begin{tabular}{c|r|r}
\hline 昭和 & 男 $(\%)$ & 女 $(\%)$ \\
\hline 42 & $79(53.8)$ & $67(46.2)$ \\
43 & $83(58.1)$ & $59(41.9)$ \\
44 & $68(57.5)$ & $50(42.5)$ \\
45 & $66(56.6)$ & $56(43.4)$ \\
46 & $90(73.0)$ & $47(27.0)$ \\
47 & $102(62.9)$ & $60(37.1)$ \\
48 & $65(57.5)$ & $59(42.5)$ \\
\hline 平 & $59.9 \%$ & $40.1 \%$ \\
\hline
\end{tabular}

実験動物に男性ホルモンであるアンドロゲンを投与する と，攻撃的な行動をとるよらになることは知られてお り, 鼻出血発来原因として, このよらな行動を伴なら精 神的な活動も間接的な影響をもつものではないかと考え られる。

\section{3）年齢分布}

表 3 のごとく若年層に多く，10才までの幼小見が32 $\%$ ，次いで10代が約 $25 \%$ 占めている，加齢とともに減 少の傾向がみられる，本邦では渡部 ${ }^{1)}$ ，渡辺 ${ }^{3)}$, 白岩2)ら つ報告があり，いずれも20才前後の青年層にピークをみ ている. 外国では, Wright \& Smith ${ }^{5}$ は青年期に多い とし, Hallberg ${ }^{(3)}$, Kirchner ${ }^{7}$, Hara ${ }^{8)}$, Juselius ${ }^{9)}$ の報 告では，50才以上の高年齢層に高率であるとしている．

これには症候性鼻出血も含まれているので，高㱓化した ものと考えられる．著者の調査では幼小児の増加をみて いるが，幼小児では一概に自発性鼻出血とはいえない場 合も少なからずあり，その判定に穹することも多、幼 小児では乾燥性前鼻炎, 鼻炎などの鼻前庭, 鼻腔内の炎 㱏を背景として, 鼻腔一の直接的, 閒接的な機械的刺

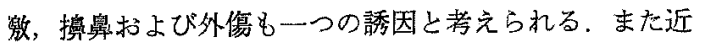
年, 親の小坚疾患に対する関心が増大したことも，小児
舅出血患者数の増加をみた一因であろう。しかし幼小見 といえども，何年間も出血が反復する症例が多数あるこ と，またキーゼルバッ八部位，鼻底，鼻腔深部からの出 血もみられることにより，す心゙てが機械的，外傷性要因 によるむのと片付けることはできない 豊田10)らは富山 県大気污染地区において，近年小坚の鼻膛を中心とした 炎症性, アレルギー性上気道炎の增加を報告している。 Walker ${ }^{17}$ は小坚鼻出血の60例の5ち，約73\%にアレル ギー素因をみて掠り，Hara はまた，種々の原因による 鼻炎，アレルギー性鼻炎を再発性の鼻出血の素地として いる.この意味では，大気污染などの環境的な影響む無 視できないと考えられる.

\section{4）年㱓別男女分布}

各年齢層において，男子が女子に比し多数である（表 3). 前頃の年跉分布のところでみたように，やはり男 子では10才以下が圧倒的に多く，10代の思春期層がこれ に次いでいる，女子では20代までは，ほぼ同率であり， 特に増加をみる年代はない，唯一，20代では男子に比し 女子が多いが，試みに精神的にも，肉体的にも過渡期と される15才〜24才の男女別を行ら上，男子 $43 \% ， 女 子 52$ \%となり，これも女子が高率である(表 3 下段)，市原11 に上ると，婦人に扔いて代償性扝上び補充性月経として の鼻出血は12.1\%に認められること，また妊娠と鼻出血 については，妊婦の7.4\%にこれをみることを示崚して いる.こ扎ら女性性周期に扔ける特殊な出血を，男女比 の多少に影響するものと思われる。

表 3 鼻出血患者の年龃分布

\begin{tabular}{|c|c|c|c|c|c|c|c|c|c|}
\hline \multicolumn{2}{|r|}{$0 \sim 9$} & $\begin{array}{r}10 \sim \\
19\end{array}$ & $\begin{array}{r}20 \sim \\
29\end{array}$ & $30 \sim$ & $40 \sim$ & $\begin{array}{r}50 \sim \\
59\end{array}$ & $\begin{array}{r}60 \sim \\
69\end{array}$ & \multicolumn{2}{|l|}{$70 \sim$} \\
\hline 男 & 187 & 117 & 55 & 41 & 45 & 49 & 35 & 24 & 553 \\
\hline 女 & 106 & 108 & 90 & 21 & 23 & 22 & 20 & 8 & 398 \\
\hline 弇敦 & 293 & 225 & 145 & 62 & 68 & 71 & 55 & 32 & 951 \\
\hline \multirow[t]{4}{*}{$\%$} & 30.8 & 23.7 & 15.2 & 6.5 & 7. 2 & 7.5 & 5.8 & 3.4 & \\
\hline & & & $15 \sim 2$ & & -2 & & & & \\
\hline & & 男 & 93 & $\begin{array}{l}i \\
i\end{array}$ & $3 \%$ & & & & \\
\hline & & 多 & 124 & & $7 \%$ & & & & \\
\hline
\end{tabular}

5) 月別患者分布

7 年閒を総合すると， 5 月を頂点として，5月〜 8 月 の夏期に多い山型であり，3月に若干の增加定示してい 


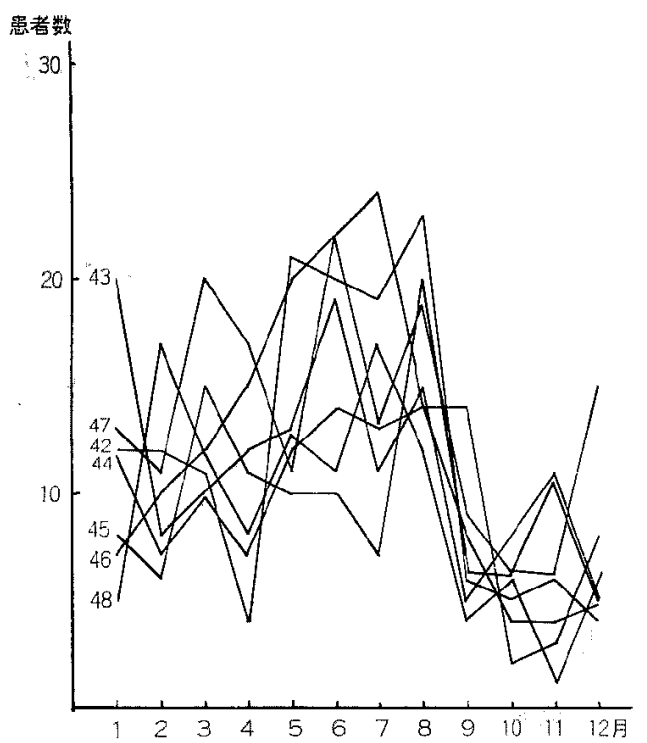

図 17 年間の月別患者分布

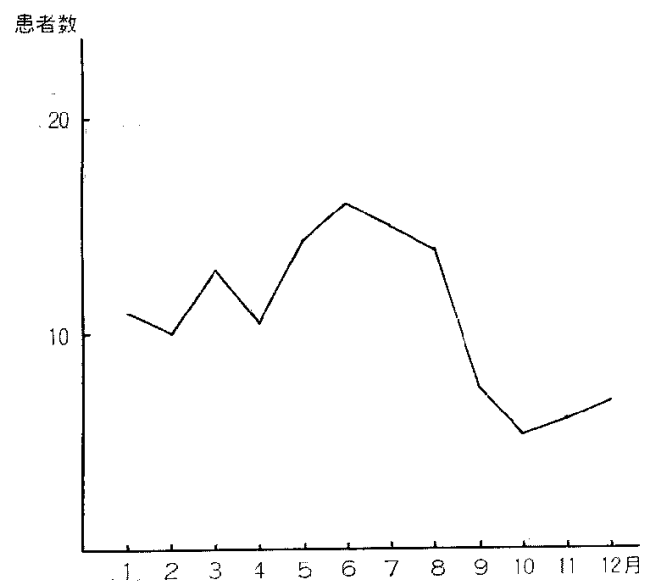

図 2 平均月別患者分布

る(図 1，2）。渡部らは月別患者数の男女別を行い，男 子に怙いては 3 月，6月の季節変動期，女子では 7 月， 8月の夏期に多いとしている。白岩 ${ }^{2} ら$ は 8 月， 7 月， 3月に多いと報告している．われわれは男女别分類を行 ってはいないが，これら報告とほぼ一致すると考えてい る、本邦に扔いては，鼻出血は 3 月，また6月から8月 の夏期に多いとみるのが妥当なよらである，米国では，

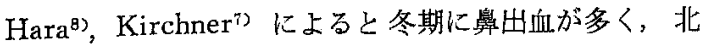

欧では Juselius ${ }^{9)}$ の統計がありこれれまた冬期に多い としている. 本邦と外国との，この季節的な差が何に起 因するのか不明であるが，人種的な相違，生活環境，ま た気象的な差異によるものかもしれない

\section{第 II 章 鼻出血と気象}

第 I 章において，鼻出血に対する気象の影響を推測 し，月あるいは季節により鼻出血患者数の変動が認的ら れたことにより，鼻出血と気象状況との関係を検討し た。気象状況としては，当地方における月別平均気圧， 月別平均気温，月別平均湿度の 3 つを取り上げ，月別鼻 出血患者数と比較した．図 3 は 7 年間のそれぞれの気象 状況と，鼻出血患者数を月別に平均したグラフである. これでみると，鼻出血と気温との相関は否定できないが， 鼻出血上湿度との相関はみられない，てして，凨出血と 気圧上の逆相関が示唆される。更に推計学的に検討する と図 4，図5のごとく鼻出血と気温，湿度との相関はみ られなかった。しかし気圧低下時に鼻出血の増加をみる という，気圧との逆相関がみられた(図6)。この相関は 月別患者数と月平均気圧との関係であって, 気圧は日時 汇変動するものであるから，経時的な気圧変動と鼻出血 との調查は今後の課題と思われる.

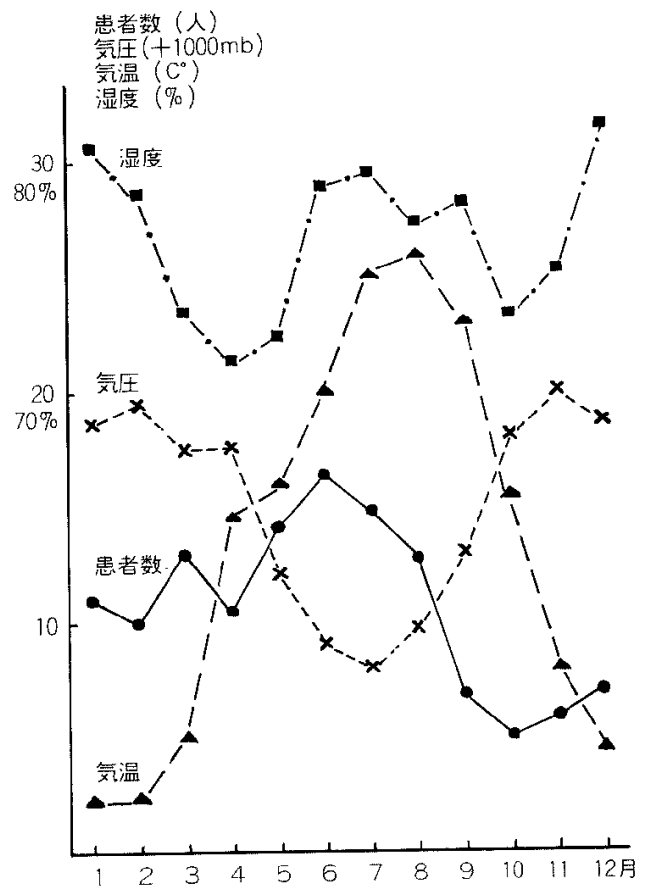

図3 年間の患者分布と気象状況 


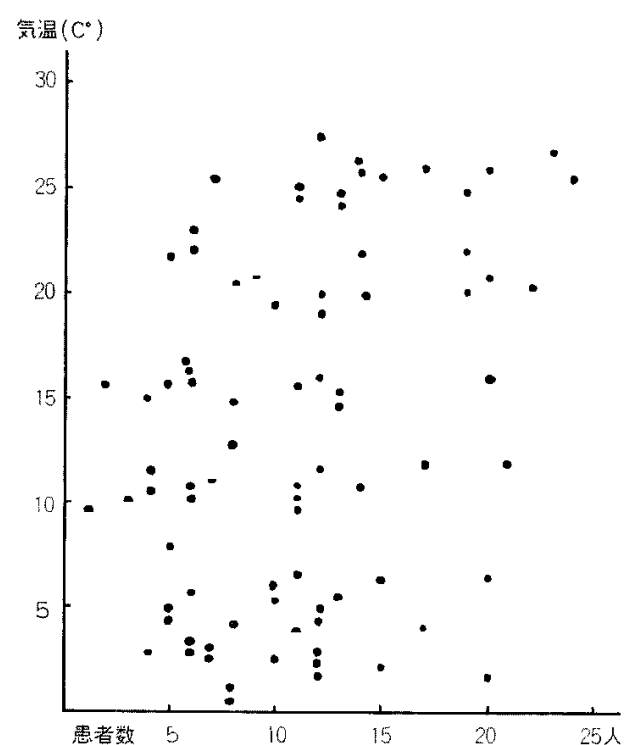

図 4 月別鼻出血患者数と月平均気温

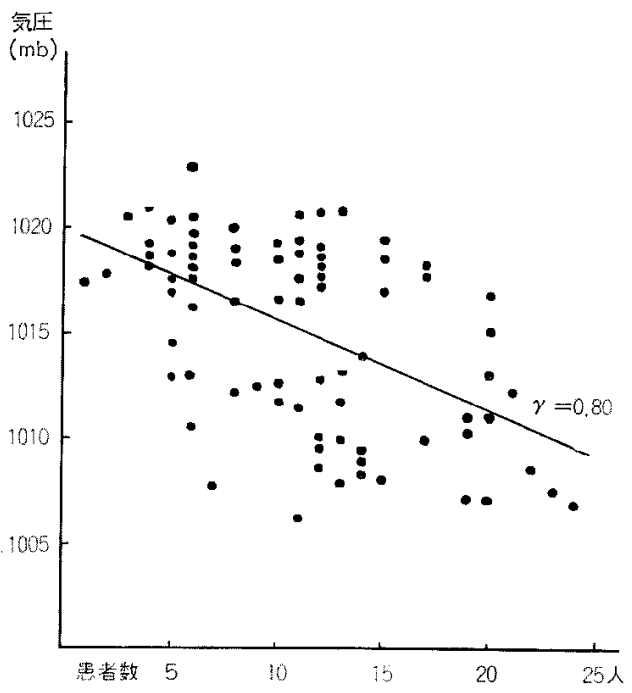

図 5 月別鼻出血患者数と月平均湿度

気圧の身体に及ぼす疾患としては，一般的に高高度 病, 潜函病が知られて㧍り，これら疾患はいずれも低圧 環境において病状が発現している。この主病変は血管系 に招けるガス分圧の変動に上るものであるが，また血管 系に異常があるものに起こりやすいとされている，眼科 的には，気圧低下と急性亏っ血性緑内障の発病とは相関

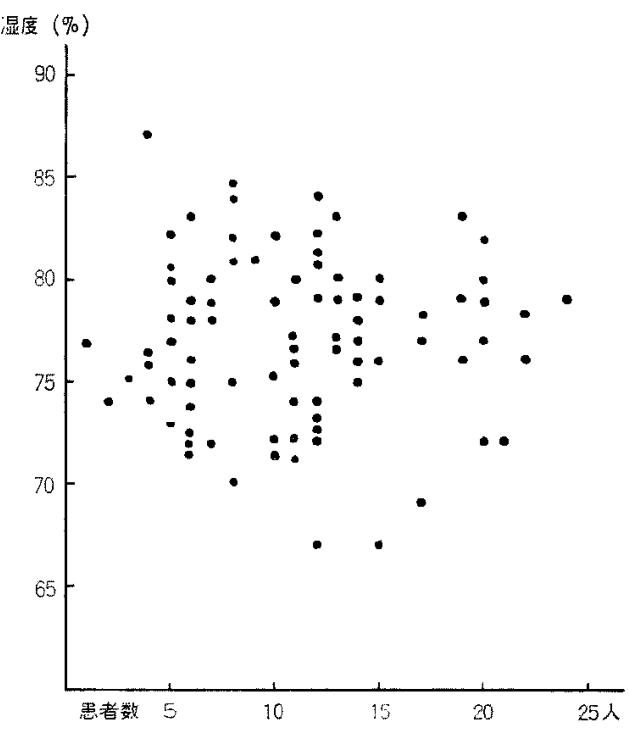

図 6 月別鼻出血患者数と月平均気圧

があることが報告されている21)，低気圧時において鼻出 血が発来する原因は不明であるが，頭頸部血流動態が重 力, 気圧の影響を受けやすいと考えるなら，循環機能の 調節が未発達なものや, 鼻腔血管が脆弱なもの, ことに キーゼルバッ八部位の血管脆弱性については白岩の報 告, また大床 ${ }^{13)}$ 電顕的研究によっても指摘されている ことであるが，このような局所的な血管性出血傾向のあ るものにとっては, 大気圧の変動が鼻腔血流動態に変化 をむたらし，直接破綻性の出血をきたしたり，また血管 透過性の增大に上り，漏出性の鼻出血が発来するのでは ないかと推測される。

\section{第而章 出血素因の有無に関する調査}

鼻出血の原因不明なもの，特に持続性のがん固な出血 に対しては，局所的な観察とともに，全身的な梌索も必 要と考えられる，当科では鼻出血患者住対し，ルーチン なテストとして出血時間, 凝固時間, 血小板数, 毛細血 管抵抗訊験 (Rumpel-Leede 引っ血試験)を行っている が，これらに異常をみたもの，また異常をみなくとも反 復性，持続性に出血をみる症例に対しては，更にプロト ロンビン時間(以後プ時間とする), 部分トロンボプラス チン時閒 (PTT), フィブリノーゲン量, 線溶能を測定 した。 プ時閒は Quick一段法, PTT は Langdell 法, 線溶能はユーグロブリン溶解時間法により測定した，鼻 出血患者に対しルーチンに出血時間, 凝固時間, 血小板 数，毛紐血管抵抗試験を行らことは，出血が血管壁の異 常によるものか，血小板减少によるむの文，あるい性凝 


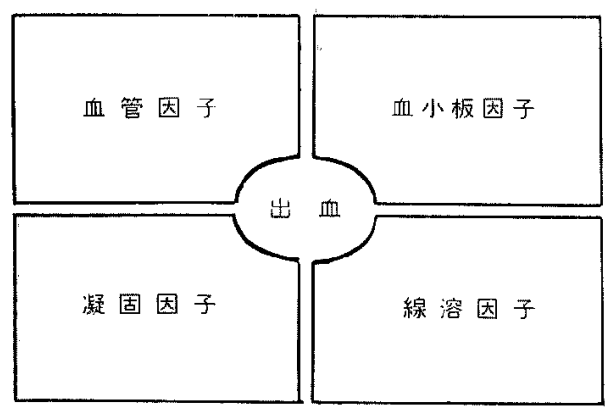

図 7 出血因子

固因子, 線溶能の異常に基つくくものかをスクリーニング するものとして有用であると考えられる（図７）.

対象として，昭和 48 年，49年の 2 年間に鼻出血にて受 診した 114 例について, これら出血素因に関する検索 を行った. 114 例中, 検查上異常を認めたものは32 例 （28.1\%）であった．そのうち血管壁の異常に基づくと 考えられるむのは19例（17.7\%）であり，血小板減少 2 例 $(1.8 \%)$, 凝固因子異常 3 例 $(2.6 \%)$, 線溶機能異常 3 例 $(2.6 \%)$ であった。そ他 5 例に出血時閒のみの 延長をみた（表 4)，血管因子異常19例のうち，RumpelLeede うっ血試験にて陽性 (H) 以上のものは9例 (7.8 \%)であり，これは確実に病的であり，全身的な出血傾 向があると考えられる，他10例は弱陽性(十)であるが， 正常人でもこの程度はうっ血斑の出現をみることがあ り，病的とは判断し難く，血管壁抵抗の減弱が疑われる ものであろう．血小板減少をみた 2 例は血小板数 8 万斿 上び 7 万であり，Rumpel-Leede うっ血試験にていずれ 屯(H)，出血時間柱 7 分，10分と延長をみている，凝固 因子異常が疑わ机る 3 例の内訳は，2 例にPTT の延長 とプ時間の軽度の延長があり, 他 1 例恃プ時間が 27 秒で あった．線溶機能六進をみた 3 例のうち，2 例はューグ ロブリン溶解時間が 2 時間であり, 他 1 例は 1.5 時間と 線溶活性化傾向がみられた（表 5 ）。

以上 32 例 $(28.1 \%)$ に全身的出血傾向に関する検索に おいて異常がみられたが，血管因子異常が疑われるもの が最も多く，これは容易に何らかの唀因に上り鼻出血を ひき起こすと推測される. 凝固因子の巽常が疑われるも のは $2.6 \%$ 上少数ではあったが，これるまた何らかの誘 因により出血がひき起こされるその背景となる可能性が 大きいと考学られる．線維素溶解現象の本来の生理的機 能は，血管内血液凝固を阻止するものであるが，この作 用が生理的範围を超え，強く活性化されるようになる
表 4 出血素因に関する検查結果（114例）

\begin{tabular}{cc|c|c}
\hline 血管 因子 異 常 & 19 & $17.7 \%$ \\
\hline 血小 板 減 少 & 2 & $1.8 \%$ \\
\hline 凝 固 因子 異 常 & 3 & $2.6 \%$ \\
\hline 線 溶 機 能 異 常 & 3 & $2.6 \%$ \\
\hline $\begin{array}{l}\text { その他, 出血時間のみに } \\
\text { 異常をみたもの }\end{array}$ & 5 & $4.4 \%$ \\
\hline 異 常 検 出 全 数 & 32 & $28.1 \%$ \\
\hline
\end{tabular}

表 5

血管因子巽常

Rumpel-Leede (H) 以上のもの 9 例

Rumpel-Leede (+)のもの 10例

血小板減少

症例 1 出血時閒 7 分

Rumpel-Leede (H)

血小板数 $8 \times 10^{4}$

症例 2 出血時閒 10 分

Rumpel-Leede (H)

血小板数 $7 \times 10^{4}$

凝固因子異常

プ時閒 PTT

症例 $3 \quad 16.5 \quad 146.5$

症例 $4 \quad 16.6 \quad 203.4$

症例 $527.0 \quad 66.6$

線溶機能異常

$\begin{array}{ll}\text { 症例 } 6 & 2.0 \text { 時間 } \\ \text { 症例 } 7 & 1.5 \text { 時間 } \\ \text { 症例 } 8 & 2.0 \text { 時間 }\end{array}$

と，線維素溶解性紫斑病に代表される出血傾向を生しるる ことになる，この線溶性紫斑病は外科手術，ショック。 白血病，肝実質障害，悪性腫境などでも出現することが あり，また線溶活性化は精神的興㝐, 運動によっても起 こることがあるとされている ${ }^{18)}$. 今回，少数ではあるが， $2.6 \%$ に活性化傾向をみたこと法，鼻出血に打梳る線溶 因子の関与も軽視できないものと考えられる，鼻出血と いら局所的な現象に限るなら，このような全身的な活性 化傾向に対し，鼻腔領城の局所的な線溶系の関与も考應

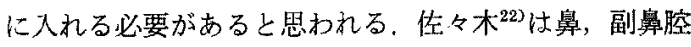


粘膜の線溶作用を組織学的に検討し，その線溶作用は静 脈，細静脈に存在することを示した。 Rasmussen ${ }^{23)}$ は 下鼻甲介粘膜に強い線溶能が存在するとし，この部位か らの鼻出血の際には, 循環血液中の線溶能に対し, 出血 により得られた血液中には強い線溶能が存在したと報告 している，鼻腔は種々のアレルゲン，粉塵, 細菌, また 気象変化などの外的環境を直接受け入れる門戸であり， このような刺激に対し 鼻粘膜，あるいは鼻腔内血管の tissue activator による直接的な局所の過度の線溶活性 化が起こることもあるのではないかと推察される。

\section{第IV章 小児鼻出血と偏食}

第 1 章でみたごとく，鼻出血患者の年齢分布では 0 9 才までが $32 \%$ \%゙あ，10代む加えると約56\%に到り， 半数以上を占めている，小児鼻出血患者を問診してみる と，患児が偏食しがちであると訴える親にしばしば遭遇 した. 小児は種々の面で成長過程にあり，偏食法時に精 神的にも肉体的にも重大な影響を与える場合があると考 えられ，この点より小児鼻出血と偏食につけてての調查を 行った．対象としては，昭和46年から49年の 4 年間に自 発性鼻出血と診断した 2 才から15才までの幼小児および 小中学生 199 人であり, 主に食品嘹好傾向を中心とした アンケートを郵送した（表6）。対照群としては，高岡 市 1 小学校の協力を得て, 1 年生加 6 年生までの生徒 各 1 学級を無作為に選び, 同様のアンケート調查を行。 た．患者群と対照群とには大きな環境の相違はない ア ンクートの内容は食品嘴好関するものが主であり：他 に2，3の質問項目を付加し，対照群における鼻出血多 発者を除外するための項目を取り入れた。

偏食には各食品の摂取量, 調理内容なども関倸する が，この種のアンケートではこれらにまで言及するこ上 はできなかった。したがって，今回の調查は各個人の偏 食程度を測定することはできず，ただ偏食傾向を推測す るだけのものと考える。アンケートの食品内容は簡略な むのとし, 倞肉, 魚, 納豆などの蛋白質群, 牛乳, 小魚 などのカルシウム群, 人参, ピーマンなどのビタミン $\mathrm{A}$ 群, 大根, キャベッなどのビタミン C 群, 他に脂肪群, 炭水化物群の 6 群に大別した（表 7 ).

㭧者群と対照群において，これらのおのおのにつき比 校検討した，患者群において返送されてきたアンケート は121通でありここれは全郵送数の60.8\%である。この 回答率怯，この種のアンケートとしては娰比すべき報告 を持ち合わせてはいないが，かなりの高率ではないか上 考えられ，鼻出血に対する関心が案外大きいと推測され

\section{表 6}

$$
\boldsymbol{P} ン \boldsymbol{ケ}-\boldsymbol{1}
$$

最近新聞紙上でも騒がれましたが，小児の鼻出血（は なぢ）が問題となって扔りますこどもの突然の鼻出血 を経験され，鳘加れた找様方す少なくないと思いま す. 放置して扔いても自然に止血する場合が多いもので すが，血液疾患のあるもので怔此血困難なものもありま す 私達は数年来この問題に取りくんでおりますが, 今 回鼻出血と偏食について調查を行ない，治療の一助とし たく思っておりますので，御多忙中恐縮ですが，下記の 項目に回答の上，御返送下さる様打願い致します。

1 該当項目を○でかこんでたさい

- 性別 (男・女) - 年齢 才（幼稚園，小学校 年, 中学校 年) - 住居 (住宅地 - 農村 - 魚村 · 山村)

2 あなたは鼻出血（はなら゙）を経験された事がありま すか。(はい・いいえ)

「はい」と答えた人は次の項目に○をつけて下さい

$11 \sim 2$ 度はなぢが出た。

口 1 年に何回もはなぢが出る。

八はなら゙が出ても，すぐ止まる。

ニはなら゙で医者に診てもらった事がある。

木 鼻に触れたり，打った時にはなら゙が出る，

、はなぢが出る時は1日の5ちで（朝・昼・晚・勉 強中・睡眠中）に多、

3 次にあげる食品で好きなもの○きらいなもの×普通 வをつけて下さい

鯨肉（）マトン(羊肉)（）とり肉（）豚 肉（）卵（）納豆（）魚（）豆腐 ( ) 八厶（） ウインナー（）牛乳（） チーズ（）小魯（）海草こんぶ（） 人参

（）ほうれん草（）大根（） ピーマン

( ) 加恬や( ) き中5り（） パン（） キャベッ（）たまねぎ（）バター（）ご はん（） マーガリン（） じゃがいも（）

さつまいも( )

御協力ありがとらございました。

る．第I 章，鼻出血患者の年齢分布の項に招いて，小児 の鼻出血の原因に注鼻前庭, 鼻腔内の炎症を背景とし て，鼻腔への機械的な刺激や外傷が trigger となる場合 がかなり多いのではないかと推察した。アンケートに付 加した質問項目に対する回答では，番出血患者群では機 械的また外傷性誘因により出血をみたと考劣られるむの は36人（25.6\%)であった。これより確かに，小児では 譏械的また外傷性の算出血は大きな比重古占めている 
表 7

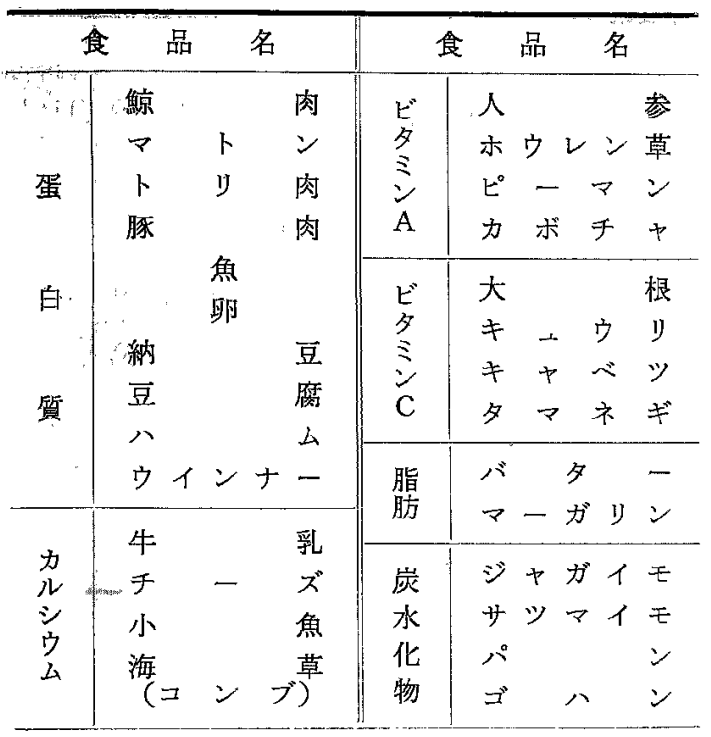

表 8 鼻出血好発時間

\begin{tabular}{|c|c|c|c|c|}
\hline 好 & 発 時 & 間 & 回 答 数 & $\%$ \\
\hline & 朝 & & 30 & 24.8 \\
\hline & 笪 & & 17 & 14.0 \\
\hline & 堍 & & 16 & 13.2 \\
\hline 勉 & 強 & 中 & 1 & 0.8 \\
\hline 睡 & 眠 & 中 & 50 & 43.8 \\
\hline
\end{tabular}

が，約 $74 \%$ 多数が原因不明と考えられる，畧出血患者 群における鼻出血好発時間であるが，表 8 のごとく睡服 中が最も多く，43.8\%を占めている．睡眠時に鼻出血を 多数みることは，もらろん睡眠中無意識に鼻腔をさわっ たりするような機械的な操作を否定はできないが，全部 肪そうと言い切ることもできないと思われる，その機序 は不明であるが，機械的，また外倠性誘因以外の因子の 関与を，㐫る程度支持してくれるものと考えられる．

対照群として, 計 230 人の回答を得た。 この内，警く ことに 180 人 (78.3\%) の鼻出血経験者をみたが，その 約 $96 \%$ ののは過去 1 ～回の出血にすぎぬものばがり であり，この出血が外傷性誘因によるものとはっきり答 えたものは約30\%であった。他は原因不明とのことであ った，刘照群に括いて，反復性の鼻出血，末たがん固な 鼻出血化て医師を受診したことが西る览童は 7 人であっ た。これらは食品啫好調查において推計学的に検定する 祭，対照群加ら除外した。患者群にて約 $26 \%$ ，东た対照 群にて約 $30 \%$ の外傷性, 西るい性機械的彭因に上る鼻出 血を知ることができた。これより，小児では機械的，外 傷性誘因による鼻出血は大きな比重を占好ていが，約 $70 \sim 74 \%$ ものが原因不明であり，例えば鼻腔血管の脆 弱性などを中心として, 種々の要因が複雑に絡まり合。 ているものと考えられる.

食品蹧好に関与る回答より，鼻出血患者群と対照群上 を比較検討した，一般に，小肾は好きなむのに対しての 容認的な反応よりも。きらいなものに対する拒絶的な反

㤗 9 蛋 白質 群

\begin{tabular}{|c|c|c|c|c|c|c|c|c|c|c|c|c|c|c|}
\hline & & & 0 & 1 & 2 & 3 & 4 & 5 & 6 & 7 & 8 & 9 & 10 & Total \\
\hline \multirow{3}{*}{\multicolumn{2}{|c|}{ 鼻出血患者群 }} & 数 & 45 & 30 & 21 & 11 & 8 & 5 & 0 & 0 & 0 & 0 & 0 & 121人 \\
\hline & & \multirow{2}{*}{$\%$} & \multirow{2}{*}{37.2} & 24.8 & 17.4 & 9.1 & 6.6 & 4.1 & 0 & 0 & 0 & 0 & 0 & \\
\hline & & & & \multicolumn{10}{|c|}{62.8} & \\
\hline \multirow{3}{*}{ 対 } & & 数 & 87 & 59 & 39 & 25 & 8 & 3 & 1 & 1 & 0 & 0 & 0 & 223 人 \\
\hline & & \multirow{2}{*}{$\%$} & \multirow{2}{*}{39.0} & 26.5 & 17.5 & 11.2 & 3.6 & 1.3 & 0.4 & 0.4 & 0 & 0 & 0 & \\
\hline & & & & \multicolumn{10}{|c|}{61.0} & \\
\hline
\end{tabular}

$\mathrm{X}^{2}=7.613$

0：食品の5ち，その全てに対しきらいとは答えなかったもの

1 : 食品のうち，1個をきらいと答えたもの

2 : 食品の5ち，2 個をきらいと答えたもの

3 : 食品のらち，3個をきらいと答えたもの

以下同 
表10 カルシウム群

\begin{tabular}{|c|c|c|c|c|c|c|c|}
\hline & & 0 & 1 & 2 & 3 & 4 & Total \\
\hline \multirow{3}{*}{$\begin{array}{l}\text { 鼻出血 } \\
\text { 患者群 }\end{array}$} & 数 & 65 & 35 & 16 & 5 & 1 & 121 人 \\
\hline & \multirow{2}{*}{$\%$} & \multirow{2}{*}{52.9} & 28.9 & 13.2 & 4.1 & 0.8 & \\
\hline & & & \multicolumn{4}{|c|}{47.1} & \\
\hline \multirow{3}{*}{ 対照群 } & 数 & 142 & 54 & 22 & 4 & 1 & 223人 \\
\hline & \multirow{2}{*}{$\%$} & \multirow{2}{*}{63.7} & 24.2 & 9.9 & 1.8 & 0.4 & \\
\hline & & & \multicolumn{4}{|c|}{36.3} & \\
\hline
\end{tabular}

$\mathrm{X}^{2}=4.829$

表11 ビタミンA群

\begin{tabular}{|c|c|c|c|c|c|c|c|}
\hline & & 0 & 1 & 2 & 3 & 4 & Total \\
\hline \multirow{3}{*}{$\begin{array}{l}\text { 鼻出血 } \\
\text { 患者群 }\end{array}$} & 数 & 39 & 51 & 20 & 9 & 2 & 121 人 \\
\hline & \multirow{2}{*}{$\%$} & \multirow{2}{*}{32.2} & 32.7 & 23.8 & 8.5 & 0.9 & \\
\hline & & & \multicolumn{4}{|c|}{67.8} & \\
\hline \multirow{3}{*}{ 対照群 } & 数 & 76 & 73 & 53 & 19 & 2 & 223 人 \\
\hline & \multirow{2}{*}{$\%$} & \multirow{2}{*}{34.1} & 32.7 & 23.8 & 8.5 & 0.9 & \\
\hline & & & \multicolumn{4}{|c|}{65.9} & \\
\hline
\end{tabular}

$\mathrm{X}^{2}=4.443$

表12 ビタミンC群

\begin{tabular}{|c|c|c|c|c|c|c|c|}
\hline & & 0 & 1 & 2 & 3 & 4 & Total \\
\hline \multirow{3}{*}{$\begin{array}{l}\text { 䔬出血 } \\
\text { 患者群 }\end{array}$} & 数 & 64 & 38 & 14 & 5 & 0 & 121 人 \\
\hline & \multirow{2}{*}{$\%$} & \multirow{2}{*}{52.9} & 31.4 & 11.6 & 4.1 & 0 & \\
\hline & & & \multicolumn{4}{|c|}{47.1} & \\
\hline \multirow{3}{*}{ 対照群 } & 数 & 139 & 62 & 21 & 1 & 0 & 223人 \\
\hline & \multirow{2}{*}{$\%$} & \multirow{2}{*}{62.3} & 27.8 & 17.4 & 0.8 & 0 & \\
\hline & & & \multicolumn{4}{|c|}{37.1} & \\
\hline
\end{tabular}

$\mathrm{X}^{2}=8.073 \quad \mathrm{P}<0.10$

応が蚛いと思われるので, 各食品群にお゙いてきらいと答 えたものの数を検定に供した（表 $9 \sim 14 ）$.

結果では，蛋白質群，カルシウム群，ビタミンA 群， 脂肪群，炭水化物群には有意の差はみられず，ただビタ ミンC群に埝て10\%の危除率で有意の差がみられた。
表13 炭水化物群

\begin{tabular}{|c|c|c|c|c|c|c|c|}
\hline & & 0 & 1 & 2 & 3 & 4 & Total \\
\hline \multirow{3}{*}{$\begin{array}{l}\text { 鼻出血 } \\
\text { 患者群 }\end{array}$} & 数 & 117 & 3 & 1 & 0 & 0 & 121人 \\
\hline & \multirow{2}{*}{$\%$} & \multirow{2}{*}{96.7} & 2.5 & 0.8 & 0 & 0 & \\
\hline & & & \multicolumn{4}{|c|}{3.3} & \\
\hline \multirow{3}{*}{ 対照群 } & 数 & 216 & 6 & 1 & 0 & 0 & 223 人 \\
\hline & \multirow{2}{*}{$\%$} & \multirow{2}{*}{96.9} & 2.7 & 0.4 & 0 & 0 & \\
\hline & & & \multicolumn{4}{|c|}{3.1} & \\
\hline
\end{tabular}

$\mathrm{X}^{2}=1.399$

表14 脂肪群

\begin{tabular}{|c|c|c|c|c|c|}
\hline & & 0 & 1 & 2 & Total \\
\hline \multirow{3}{*}{$\begin{array}{l}\text { 鼻出血 } \\
\text { 患者群 }\end{array}$} & 数 & 108 & 6 & 7 & 121 人 \\
\hline & \multirow{2}{*}{$\%$} & \multirow{2}{*}{89.3} & 4.9 & 5.8 & \\
\hline & & & \multicolumn{2}{|c|}{10.7} & \\
\hline \multirow{3}{*}{ 対照群 } & 数 & 190 & 20 & 13 & 223 人 \\
\hline & \multirow{2}{*}{$\%$} & \multirow{2}{*}{85.2} & 9.0 & 5.8 & \\
\hline & & & \multicolumn{2}{|c|}{14.8} & \\
\hline
\end{tabular}

$\mathrm{X}^{2}=1.818$

すなわち，鼻出血患者群ではビタミンCを含む食品をよ り好まないといら傾向が推測されるといらことであり， これはビタミンCの血管に怙ける作用といら点からみる と興味のあることと思われる。

考按

病理学的には，出血は破綻性出血と漏出性出血に分類 される. 破綻性出血は血管壁の損傷により，動静脈の、 ずれの部分にでも起こり得るものであるが，漏出性出血 は細静脈に特有なものとされ，種々の要因，例えば烦症 による血管透過性亢進が背景となる場合が多い従来， 毛細管出血（実質性出血）といわれていたのは，すべて 細静脈部の漏出性出血と訂正されつつあるようである ${ }^{12)}$

畧出血が破綻性出血によるものか，あるいは漏出性出 血によるものかといら闍題は，個々の症例により判別す べき事柄であるが，䣒床的にはその鑑別は困難である.

鼻骨骨折，颜面外旐などによる原因の明らかな大量出血 の際には，これは破綻性出血と言いきることができる が，日常外来を訪れる鼻出血患者の原因は，ほと儿どが 
自発性といら意味において不明であると言っても過言で はない，小児においては，成年層以上，特に高齢者の鼻 出血に比し，出血点を求めることさえ難しく，単にキー ゼルバッ八部位の充血をみるだけの症例が少なくない これが種々の原因による炎症，あるいはアレルギー，自 律神経異常などによる血管反応としての充血を示すむの ならば，極めて漏出性出血の可能性が大きいと考えられ る。しかし，小児の鼻出血において破綻性出血が否定さ れるかといらと，一概にそうとむいえない，第 I 章，第 IV章においてみたごとく，小児では機械的刺激，外傷に よるとみられる鼻出血がかなりの数を占めていることに より，血管壁損傷による破綻性出血が多数あると思われ る. 動静脈の血管壁の強弱という点からみると，何らか の機械的, 外傷性の誘因があっても，細静脈壁の脆弱性 ゆえに，破綻性出血といえども細静脈部からの出血がよ り多いのではないかと考えられる。

白岩 ${ }^{219}$ によると，解剖学的にキーゼルバッ八部位に は多数の上皮内血管が認められ，上皮直下に毛細血管 網, 深層では静脈丵の分布と種々の形態の動静脈吻合が 認められるという。また6例の自発性鼻出血患者のキ一 ゼルバッ八部位の粘膜を病理組織学的に検討し, 上皮下 小静脈の洞様の拡大, 静脈瘤などの易出血状態をみてお り, 深層小静脈柱紡錘状に開大し, 充血, 血流緩慢, 静 止，血栓形成などむ認められると報告している。これは 炎症時にみられる血管反応に類似しており，畣出血時に おいてこのよらな炏症性血管反応と類似した病態が認め られることは, 鼻出血が単なる血管の破綻によるものだ けでなく，漏出性成分をも伴っているもの上想像され る.

鼻腔の末梢循環において，その脆弱性により，細静脈 が出血の場であり, 鼻出血に抢ける漏出性出血の可能性 を述べてきたが，その血管壁の脆弱性に影響を及ぼすも のは何かといら問題がある. 第V章, 小児偏食の調査に おいて，鼻出血小巟がビタミンCを含む食品をよりきら らといら傾向をみることができた. ビタミンCの生体に 対する作用は, 細胞間物質の生成と保持にあるとされて いる14) とくに血管系で注，内皮細胞間のセメント物質 の維持に必要とされている，またコラーゲンの主成分で ある hydroxyproline, 結合織ムコ多糖類の形成に重要 な衝きをむち, 血管壁の強化, 維持に与っている、ビタ ミンC尔乏は血管壁の脆弱性となって現われ，代表的疾 患としては壊血病がよく知られている. 大本 ${ }^{13}$ による と，軽度の鼻中隔彎曲症をもつ15例炕いて，電顕形態
学的にキーゼルバッ八部位の粘膜上皮細胞の結合の脆弱 性をみている. 他の臟器血管に比し, 鼻腔血管が本態的 に脆弱性を有するものであるなら，これに加えて，ビタ ミンCの影響は鼻腔血管に対し更に鋭敏に反映されると 思われる。

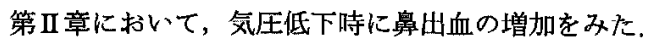
これは鼻出血が身体的な要因に加えて，環境要因にも左 右されることが推測される。気圧の急激な変化により起 こる航空中耳炎に関寸る報告として，込田 ${ }^{15}$ は実験的 に，モルモットの中耳腔に充血，出血をみている，また 江川|16) は，猫に扔ける実験的気圧変化時の中耳粘膜の病 理所見として, 粘膜上皮の腫脹, 粘膜下結合織の浮腫状 肥厚, 血管の充血, 粘膜下出血をみると報告している. このような気圧性外傷 barotrauma が葛腔に対し，いか に働くかは不明であるが，中耳腔に扔ける病態が鼻腔に おいても，大なり小なり起こっても不思議ではないと考 えられる. 気圧変化時における, 鼻腔内圧の変動, 鼻腔 内血流動態などの検討は今後の課題と考えられる。

\section{結語}

1) 昭和 $42 \sim 48$ 年の 7 年間に当院耳鼻咽喉科を受診した 951名の自発性鼻出血患者の統計的観察を行なった.

鼻出血患者の外来患者総数化対する比率は約 $3.7 \%$ で あった。性別頻度では若干男子に多く，年龄的には若年 者が多数であった．月別に患者を分類すると，6月を頂 点として 5 月から 8 月の夏期に多い山型であった。

2）鼻出血已気象状沉について検討し，鼻出血患者数と 気圧との逆相関がみられた。

3）舅出血患者について，全身的な出血素因の有無につ いて検討し，約28\%に何らかの異常がみられた。

4）小児鼻出血上偏食との関係を調查し，小児鼻出血患 者では，対照小児に比べビタミンCを含む食品をより好 まないといら傾向がみられた。

5）鼻出血が細静脈を場とした漏出性出血の可能性につ いて考察し，ビタミンCの血管への作用について言及し た.

6）気圧性外賃の鼻腔への影響について推論した。

\section{文献}

1) 渡部泰夫, 小扳四誉志夫, 中村敏治, 圽井 建, 福

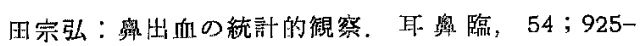
931, 1961.

2 ）白岩陖雄：舆腔，胭頭領域の出血飞関する研究。日， 本耳鼻咽诶科学会第60回総会, 1959.

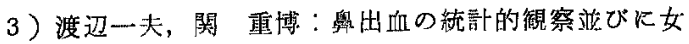




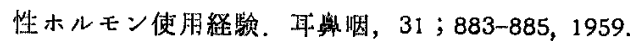

4) William, F. Ganong: Review of Medical Physiology. 3rd Edition. 1967.

5) Wright \& Smith: Disease of the Nose \& Throat. 216-218, 1914.

6) Olav E. Hallberg: Severe nosebleed and its treatment. The Journal of the American Medical Association 148 ; 355-359, 1952.

7) John, A. Kirchner: Surgical treatment of nasal hemorrhage. Surgery $50 ; 899-904,1961$.

8) H. James Hara: Severe Epistaxis, Arch Otolaryngol $75 ; 258-269,1962$.

9) Holger Juselius: Epistaxis. J. Laryngol Otol LXXXVIII ; 317-327, 1974.

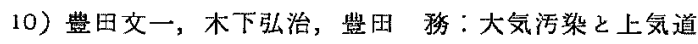
富山累竖村医学会雑誌, 4；75-81，1973.

11)，方原正雄：女性々的現象の率科領域に及ぼす影犁。 耳-舅咽。 $25 ； 609-640,1953$.

12）天野重安，川野清于，山本宽，安平公夫，平田6 と夫：小溯脈の病理.日本痛理学会々誌, 39;19-21, 1950.

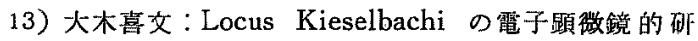
哭。日耳鯜, $68 ; 298-304,1965$.

14) W. Anderson: Pathology. VI Edition: 523-524, 1971.

15）迲由幸夫：高空性中耳障書(いわゆる高空性中耳炎) の研究。新鼬医学会䧴誌, $69 ; 326-335,1955$.

16）江川俊治：航空中耳炎の病因和上び中耳病変に関す

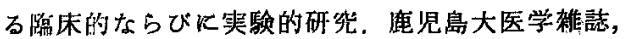
$18 ; 100-115,1966$.

17) Donald, H. Walker: Allergy and Reccurrent Epistaxis in children. Ann. Allergy 17 ; 872-877, 1959.

18）村上文犬，門田尚武：外科監休と線維委溶解現象。

最新医学, $21 ； 284-291 ， 1966$.

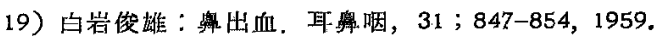

20）鳥山稂, 星野知之, 佐藤站堆：結合エストロダン 複合体の止血効果飞ついて。耳咽, $39 ; 333-336$, 1967.

21) Luner, J.\& Vaśkova, M.: Meteorotrope influences in glaucoma. CEKOSLOVENSKA OFTALMO. LOGTE 20 ; 469-472, 1964.

22）佐々木好久：率粘膜中の線稚素溶解作用の局在之そ の生理的意義。耳㚜咽，41；601-606，1969.

23) A. Buch Rasmussen: Epistaxis treated with Epsilon-Aminon-Caproic acid. Acta. Otolaryngel $61 ; 221-227,1965$.

樎を終わるにあたり，御指尊，御校閲を睗った梅田良 三教授，また終始御授助を頂いた豊田務博士に深謝いた します。な打本論文の一部は，日本耷奥咽喉科学会第 198回北陸地方会，同199回例会，第15回日本率副瞢腔学 会に和いて発表した。

（原稿受付 䀡和53.3.1日）

別刷請求先 T920 颌沢市宝町13-1 金沢大学医学部 耳舅咽喉科学教室 村田志朗 